\title{
Bengt-Arne Wickström: Öffentliche Finanzen, Fiskalwettbewerb, Nachhaltigkeit und soziale Wohlfahrt
}

\author{
Schriften des Vereins für Socialpolitik, Band 330, \\ Duncker \& Humblot, Berlin, 2011
}

\section{Juergen G. Backhaus}

Published online: 30 March 2012

(C) Springer Science+Business Media, LLC 2012

This volume on fiscal federalism took the editor, Bengt-Arne Wickström, 6 years to publish, a delay he holds himself responsible for, without hesitation.

The most interesting contribution is that by Thomas Lenk, who analyzes a change in the German at on fiscal equalization between states introduced in 2005. With this change, the German parliament implemented a decision of the constitutional court of 1999 which required a more incentive compatible system of fiscal equalization.

Essentially, the idea of the act was to create incentives for states to enhance their tax base. ${ }^{1}$ As it happens, the formulation of the act is so complex that Lenk doubts any incentive effect of the act whatsoever. What this shows is that despite the admonition of the constitutional court, fiscal equalization remains an incentive incompatible scheme which basically undermines the proper functioning of fiscal federalism.

\footnotetext{
${ }^{1}$ cf. also: Bundesministerium der Finanzen, Der bundesstaatliche Finanzausgleich, http://www.bun desfinanzministerium.de/nn_4480/DE/BMF_Startseite/Service/Downloads/Abt_V/Der_20bundesstaatli che_20Finanzausgleich,templateId=raw,property=publicationFile.pdf.

J. G. Backhaus (ه)

Krupp Chair in Public Finance and Fiscal Sociology, University of Erfurt, Nordhäuser Strasse 63, 99089 Erfurt, Germany

e-mail: juergen.backhaus@uni-erfurt.de
} 